\title{
The Fall of Kemalism and the New Face of Political Islam: 20 Crucial Years in Turkey's History (1980-2002)
}

\author{
By Maria Chiara Cantelmo*
}

\begin{abstract}
The failed coup of July 2016, while uncovering the struggle inside Turkish institutions and Islamic movement, represented the fall of Kemalism and the rise of a new face of political Islam, too. This process is not simply due to the long-lasting AKP government, but also to the deep changes occurred between 1980 (date of the bloodiest coup in Turkey's history) and the electoral victory of Erdoğan's party in 2002. These crucial twenty years lead us to reconsider the relationship between Kemalism and Islamism not as a pure dichotomy but as a complex interaction, which is better understandable in the light of domestic/international factors, Turkish Islamism's particular features and internal contradictions of Kemalist ideology. These two decades also show the continuity of some dynamics in Turkey's history, in particular the persistence of a tutelary democracy; the inclusion/exclusion of parties from the political system; the compatibility of nationalism and Islamism; the alienation of normal political order between Right/Left. Ultimately, despite their different paradigms of modernization, both Kemalist and AKP Islamic élites have preserved the "continuous coup regime". Turkish model of authoritarianism is now entering a new phase with the permanent extension of the state of emergency and the approval of the presidential reform.
\end{abstract}

\section{Introduction}

During the night of $15^{\text {th }}$ July 2016, Turkey experienced one of its most dramatic moments since the 1980 coup. The failed coup attempt generally fit Turkish military coups tradition, starting from the day chosen (Army's interventions always occurred on Fridays, after the closing of the Stock Exchange), to the statement written by the leaders of the coup and containing the language and themes typical of Kemalist tradition. The name taken by the junta - Council for the Peace at Home - reminded the Kemalist principle of "peace at home, peace in the world", which had been also affirmed by the 27 May 1960 coup's leaders. Nevertheless, this time - just like it had happened in 1960 - it was not a decision taken unanimously within a hierarchical chain of command, a concept obsessively underlined by the 1980 junta.

The fact that many people spread into the streets to defend democracy after the call made by the President of the Republic not only proved the trauma impressed on the population by several coups' legacy, but also Erdoğan's influence on a large number of supporters. The atmosphere of permanent mobilization culminated few weeks later in the Meeting for democracy and martyrs held on $7^{\text {th }}$ August in Istanbul. On that occasion, the historical symbols of Kemalism - the Turkish flag and Atatürk's picture were standing next to the picture of Erdoğan, who claimed to be the Commander in chief, a title commonly related to Mustafa Kemal. The

${ }^{*}$ PhD Student, Sapienza University of Rome, Italy. 
appropriation of Kemalist discourse by Erdoğan is one formal aspect of the greater transformation occurred in Turkey, where political stability and protection of the State are not assured any longer by the military, but rather by a government whom many observers had already accused of establishing a "civilian coup" regime and has now openly slid into a single-man authoritarianism.

Moreover, the coup revealed the power of religious movements in Turkey since, as it is known, it was allegedly orchestrated by the followers of Fethullah Gülen through their penetration into the bureaucracy and the Army, historically bastion of secularism and Kemalism. The Hizmet ("Service") movement had been accused for some years of creating a "parallel structure" responsible for non-military coup attempts, in particular after the corruption scandal involving the government in December 2013. So far, the National Security Council officially included the Gülenist movement among the terroristic threats under the definition of Fethullah Terror Organization.

Actually, such a struggle for power inside the institutions and the Islamic movement is also emblematic of a political revolution, namely the fall of Kemalism and the beginning of a new stage in Turkish political Islam. Such a process is not simply the product of the Justice and Development Party (AKP)'s long-lasting government: in fact, fundamental changes occurred during the twenty years between the bloody military coup of 1980 and the victory of Erdoğan's party at the elections of $3^{\text {rd }}$ November 2002. Focusing on this period of Turkey's contemporary history permits to recognise elements of continuity and permanent tension in Turkish political life. It also leads us to reconsider the specific features of Turkish political Islam and Kemalist experience, with the aim of better understanding the paradigms of their reciprocal interaction, evolution and relation with the State.

\section{The Crucial Twenty Years}

September 12, 1980 has been described by many as the "year zero" ${ }^{1}$ of contemporary Turkey: the military intervention realized by General Evren's junta has had until now the most lasting effects both on the juridical system (the Constitution still in force was approved in 1982) and the socio-political order. Despite the transition to civilian rule in 1983, the laws and practices of less participatory democracy ${ }^{2}$ introduced in 1980 not only imposed the ideology of national security on the institutions and political organs ${ }^{3}$; but even succeeded in creating a new type of citizen, social order and collective psychology. Moreover, the 1980 junta reformulated Kemalist ideology in

1. M. A. Birand, 12 Eylül. Türkiye'nin milad [12 September. The Year Zero of Turkey] (Ankara: Doğan Kitap, 2000).

2. See Y. Sabuncu, Anayasaya giriş [Introduction to the Constitution] (Ankara: İmaj Kitabevi, 2014), 3.

3. That is the case of Milli Güvenlik Kurulu (National Security Council), established by the 1961 Constitution but whose power was strongly increased after 1980 . 
terms of Turkish-Islamic Synthesis ${ }^{4}$, embracing Islam as an essential feature in Turkish nationalism. In this way, despite State secularism, Islamic movement could gain higher legitimacy inside the institutions, which Özal further favoured. As a decisive figure of Turkish New Right, the Prime Minister and then President of the Republic Özal promoted a radical neoliberal turn that integrated Turkey into the global market and encouraged the consolidation of Anatolian Islamic bourgeoisie ${ }^{5}$.

At the end of the Özalian decade (1983-1993), however, Centre parties proved incapable of assuring stability to the country and thus contributed to the strengthening of Islamist movement that had reorganised once again under the leadership of Necmettin Erbakan in the Refah partisi (Welfare Party). The party lived its "short Spring"6 on power between 1996 and 1997, when the National Security Council intervened on Erbakan's government with a "post-modern" coup $^{7}$ aiming to prevent irtica $^{8}$. Even so, the Kemalist restoration following the February 28 process, far from defeating Turkish political Islam, opened a phase of renewal and further rise, which had its climax in the success of the Justice and Development Party in 2002. Hence, after years of coalition governments, political and economic crisis, corruption scandals, Turkey started a real process of democratization and reduction of the Army's influence, with the goal of joining European Union. This process, as we know, finally stopped along with the extension of AKP's rule and completely reversed over the last years.

Therefore, the crucial twenty years unclosed the preconditions for a new era and show how inadequate would be a dichotomous interpretation of Kemalism and Islamism as mere expressions of centre-periphery cleavages ${ }^{9}$. Instead, the relationship between Kemalist and Islamic ideologies is based not only on a political-sociological conflict, but also on interaction and reciprocal influence, so much so that Islamic élites can be paradoxically considered a result of the success of Kemalist system ${ }^{10}$.

We should evaluate the complex paradigms of Turkish political life also in the light of some recurring elements in the country's history. After all,

4. See H. Poulton, Top hat, Grey Wolf and Crescent. Turkish nationalism and the Turkish Republic (New York: New York University Press, 1997), 181-187.

5. About the so-called "Anatolian Tigers" see E. Hoşgör, "Islamic capital/Anatolian tigers: past and present," Middle Eastern Studies 47, no. 2 (2011): 343-360.

6. See S. Aydın and Y. Taşkın, 1960 'tan günümüze Türkiye tarihi [Turkish history from 1960 to nowadays] (Istanbul: İletişim Yayınlar1, 2014).

7. See H. Cevizoğlu, Generalin 28 Şubat itirafi. Postmodern darbe [The admission of the General about the 28th February. Postmodern coup] (Ankara: Ceviz Kabuğu Yayınlar1, 2012).

8. Religious fundamentalism is considered a threat to national unity, as much as ethnic separatism, see E.J. Zürcher, "'Fundamentalism' as an exclusionary device in Kemalist Turkish nationalism", in Identity politics in Central Asia and the Muslim world: nationalism, ethnicity and labour in the 20th century (London: I.B. Tauris, 2001), 209-222.

9. See Ş. Mardin, "Centre-periphery relations: a key to Turkish politics?," Deadalus 102 no. 1 (winter 1973): 169-190.

10. Ş. Mardin, Türkiye, İslam ve sekülarizm [Turkey, Islam and secularism] (Istanbul: İletişim Yayınları, 2015), 225. 
Turkish Republic is still characterized by what historian Zürcher ${ }^{11}$ called a struggle between State and society for the adoption of a shared model of national community. Despite this struggle, the pressure exercised on the institutions by various social and political actors has assumed growing influence through a typical process of inclusion/exclusion from political life of groups and movements, often born outside the Parliament and considered dangerous or unwanted.

The expulsion or closure of political formations can be achieved through manipulation of election laws, limitations on parliamentary immunity and bans issued by the Constitutional Court: the usual imputation for Leftist parties is threatening the national unity, while for Islamic parties is violating secularism. In 2008, even AKP faced a trial that ended only with the loss of State funding for the party. Sometimes the dissolution of parties includes the expulsion of their leaders from politics (Erbakan was banned in July 2000, while Erdoğan could not run in the 2002 elections because of his past legal troubles ${ }^{12}$ ). Such a dynamic of inclusion/exclusion is even more evident in the case of Kurdish parties, repeatedly closed and re-opened under a different name. The long march of Kurdish parties stopped again in November 2016 due to the detention of several deputies from HDP (People's Democratic Party), which contributed to the radicalization of extra-parliamentary struggle. In fact, before the 2015 elections pro-Kurdish movement was not able to enjoy a legal representation, if we do not consider the numerous Kurdish citizens usually voting for Islamic parties.

It is significant that the most serious and ever-present accusations in Turkish political debate, even before July 15, have always been those relating darbecilik (coup conspiracy allegations), terrorist organization and "parallel structure", as well as "deep State" suspicions ${ }^{13}$. The coup d'état appears as a multifaceted phenomenon in Turkey's political history, which Turkish scholar İnsel called a "continuous coup regime"14 ${ }^{14}$ where the crises are handled as an instrument to enforce political hegemony and the extraordinary situations become ordinary for the whole society. The continuous coup regime, kept alive by the Army's interventions during the two decades we analyse, is nowadays evolving towards a "constitutional dictatorship regime ${ }^{15}$, as designed in AKP's presidential reform bill. In fact, the constitutional amendments approved in the referendum of $16^{\text {th }}$ April 2017 represent the final institutionalization of the suspension of regular rights.

11. E.J. Zürcher, Storia della Turchia. Dalla fine dell'Impero ottomano ai nostri giorni [History of Turkey. From the end of the Ottoman Empire to the present days] (Roma: Donzelli, 2007).

12. In 1998 Erdoğan, then mayor of Istanbul, was sentenced to ten months in jail for inciting religious hatred; just before the 2002 elections, he also faced allegations of urbanisation abuses and embezzlement.

13. Expression used to describe military or paramilitary organizations attempting on the civilian State.

14. A. İnsel, "MGK hükümetleri ve kesintisiz darbe rejimi" ["The MGK governments and the continuous coup regime"], Birikim n ${ }^{\circ} 96$ (April 1997): 15-18.

15. A. İnsel, Kesintisiz OHAL ya da Cumhurun Başkanlı̆̆ rejimi [The continuous state of emergency or the regime of the President of the Republic], accessed January 8, 2017, http://bit. ly/2g7B74y. 
The source and guarantee for this environment of "exceptionality" lie in the declaration of the state of emergency, which has turned into a habit after the failed coup but it is actually very common throughout Turkish Republic's history: recently, it was in force for twenty four years (until 2002) in SouthEastern regions troubled by Kurdish fight ${ }^{16}$. Besides facing legal or administrative requirements produced by abnormal and unexpected events, the suspension of normal rules triggers a permanent crisis atmosphere and makes ordinary the extraordinary conditions. In a sense, state of emergency is a distinctive feature of Turkish authoritarianism as a tool usually adopted by authorities in order to safeguard the State and - ultimately - their own power. In line with this approach, AKP proposed an amendment to give the President of the Republic the power to declare State emergency without consulting any other political organ. The present transition from the state of emergency to a State of emergency, with the purge of Gülenist and proKurds cadres and the violent repression of any opposition, is therefore the latest version of the structural authoritarianism affecting Turkish State at least since 1980 coup. Indeed, that military intervention marked the beginning point of a radical renovation of the Republic, which is very similar to the one currently going on. In fact, both the supremacy of executive power embodied by the President and the debates over presidential system were a post-1980 legacy recurring throughout the 90 s.

\section{Political Islam and Turkish State}

Turkish political Islam presents specific features compared to Islamic movements widespread in other Middle Eastern countries, consistently with the particular experience of Turkey as the only secular Republic in the Muslim world. This aspect, connected to Kemalist hegemony over the highest levels of Turkish State, has finally resulted in the appropriation of Kemalist rhetoric by an Islamic government. It is not just a matter of formally adopting a style of government: AKP's political Islam really seems to have taken up the Kemalist concept of power, its identification between State and party, political ideology and official State ideology.

According to Kemalists, in fact, there was no contradiction between the activities of the Republican Party and the good of the State, the nation and the Army, since politics and military both had the same purpose: safeguarding the State $^{17}$. Such a presumed harmony between national interests and political leaders is summed up in the principle of milli irade (national will), an expression frequently used by Atatürk to foster popular support for the political and military leaders. In AKP era, the same formula is a synonym for the legitimacy Erdoğan enjoys due to AKP's repeated electoral victories. This rhetoric appears particularly useful in times of crisis: it is no coincidence that

16. See Y. Sabuncu, Anayasaya giriş, 265.

17. A. Mango, Atatürk. The biography of the founder of modern Turkey (New York: The overlook Press, 1999). 
Ankara's main square was immediately renamed July $15^{\text {th }}$ National Will Square.

The idea of national will is also reflected in the Constitutional provisions establishing the supremacy of democratically elected parliamentary majority as representative of people's will; as a result, opposition is conceived as a menace to the national interests embodied by the members of the government. Furthermore, the illusion produced by Kemalist law about the fact that Republic and democracy are inseparable ${ }^{18}$ has led to a large public's support for authoritarian tendencies as long as democratic institutions are intact. Besides, Turkish electorate has always shown a preference for single-party governments, considering them more able to deal with State's problems ${ }^{19}$.

The quest for a stable government has been a crucial issue in the national security policy of the Army, too. According to Taşk $\iota^{20}$, the attitude of Turkish military towards the government is that of a tutelary democracy, where the Army detains influence and veto power over civilian politics through the bureaucratic network. The role of the President of the Republic used to balance the resulting tension between élites selected and excluded from the governance of the State, at least until he was elected by the Parliament and indirectly subject to military approval. By introducing direct election of the President in 2007, AKP subverted traditional balance and definitively put a strain on the political system sought by 1980 junta. Indeed, aiming to depoliticise the country, the leaders of the coup had tried to build a political system with a representation limited to centre-Right and centre-Left, which soon proved to be unsuitable for expressing social diversity. On the contrary, progressive weakening of the Centre favoured nationalist and conservative Right parties and played a role in the rise of the Justice and Development Party.

On the other hand, religious factor itself does have an exceptional relevance: for this reason, Turkish State exercises a higher pressure for assimilation on non-Turkish Muslim groups, while it perceives other nonMuslim minorities as alien to the national community ${ }^{21}$. Religious criterion is a necessary condition of Turkish national identity, so that it is hard to accept the existence of non-Muslim Turks or non-Turkish Muslims, as in the case of Kurds. Because of the same faith (Sunni Islam) as Turks, for a long time they have been considered "Mountain Turks" ${ }^{22}$ rather than a different ethnic community.

18.Y. Sabuncu, Anayasaya giriş, 106-7.

19. As shown in election polls, see Ö. Çaha, Türkiye'de seçmen davranışı ve siyasi partiler [The attitude of electorate and political parties in Turkey] (Ankara: Orion Kitabevi, 2008).

20. See "Prof. Dr. Yüksel Taşkn: AKP-Gülenciler kavgası, sağ cenahın "liberallerini" bu iki aktör arasında bir tercihe zorladı" ["The conflict between AKP and Gülenists forced the "liberals" of the Right front to choose between these two actors]." Politikyol. Accessed August 8, 2016. http://bit.ly/2ylz3jM.

21. F.L. Grassi, Turchia e Balcani. Materiali per lo studio degli anni recenti [Turkey and the Balcans. Materials for the study of recent years] (Romania: Napoca Star Publishing house, 2012), 5-12.

22. M. Galletti, Storia dei curdi [History of the Kurds] (Roma: Jouvence, 2004), 118. 
The importance of religious factor, too, is a paradoxical legacy of Kemalist secular State that could be built only in the historical moment when Turkey became a Muslim-majority country. Kemalist secularism is not about the classic separation between State and Church, though: on the contrary, it consists in the control of religion on public and political levels, while pushing religious expressions into the private sphere. In order to build a secular State, Atatürk had to declare the independence of the Republic from Islamic laws, which made Kemalism a sort of "reform of Islam"23: such an efficient reform that it actually encouraged the development of a Turkish form of Islam, consistent with a secular State. Significantly, both AKP and Gülen movement embraced this propaganda on the alleged exceptionality of Turkish Islam $^{24}$ as a naturally democratic, rational and tolerant religion.

In fact, first years of AKP government seemed to prove that political Islam was not only capable of entering the institutions without putting their secularism into danger, but also of enhancing democratization. Nevertheless, the integration of Islam into the public sphere is complicated by the longlasting repression of heterodox religious expressions and the internal contradictions of Turkish Islam, which is doubly political. Firstly, because Islam itself bears exclusive demands, which can be used for political purposes; secondly, because Kemalist State developed a policy for religious reform, not to mention that Turkish Army has habitually used religion to motivate new recruits to be loyal to the State.

Moreover, political Islam in Turkey was actively supported against communism. In this respect, Kırbaşoğlu ${ }^{25}$ - an exponent of social Islam reminds the "Green Generation" project, promoted by United States during the Cold War to contain the Red Scare in the turbulent Middle Eastern region. Later on, precisely the Gülen movement was fostered as a way to get Turkey closer to Central Asian Republics born on the ruins of USSR. Muslim pious organizations (just like Hizmet) appeared ideal for the purposes of pro-Western Islam and interreligious dialogue against anti-American unrest.

In the 90s, even Erbakan softened anti-Western discourse, laying the foundations for AKP's pro-Western policies. However, at the time of victory in 2002, because of the lack of sufficiently trained cadres the party accepted to rely on the Gülenist movement to consolidate its power. This was also possible thanks to the trials for conspiracy held between 2008 and 2012 against Kemalist and pro-Asian sections of military and civilian bureaucracy.

23. According to Atatürk's publicist Falih Rıfkı Atay, see A. Mango, Atatürk. The biography of the founder of modern Turkey, 532-539.

24. Elizabeth Özdalga underlined that the concept of "Turkish Islam" is connected to nationalist discourse on the alleged exceptionality of Turkish culture and history, as opposed to Arab Islam, see "The hidden Arab: a critical reading of the notion of "Turkish Islam," Middle Eastern Studies 42, no. 2 (2006): 551-570.

25. See "Hayri Kırbaşoğlu: Komünistler bize "Sizin kıbleniz 6. Filo" diyorlard1, haksız değillermiş!" ["Comunists used to tell us "Your qiblah is the Sixth Fleet", they were not wrong!"], Politikyol, accessed August 16, 2016, http://bit.ly/2xWR1s2. The project we are talking about (which refers to green as a symbolic colour of Islamism) was prepared during Carter's presidency by the National Security counsellor Brzezinski. 
Later on, the Gülenists, whose influence in the justice system and in the Armed Forces had largely grown, started targeting the intelligence and the government itself, making the breakup inevitable. This conflict is also emblematic to understand the importance of bureaucracy, which was left untouched under both Kemalist and Islamic regime. Bureaucratic apparatus has been an essential piece for the survival of tutelary democracy and fertile ground for the coups that have progressively turned from the classic military interference into the indirect intervention of bureaucratic platforms ${ }^{26}$.

\section{The Awakening of Islam in Turkey}

The success of political Islam in Turkey manifested in the wider context of the return from exile of religions ${ }^{27}$ on the international scene, as a reaction to the secularization imposed by modern $\mathrm{States}^{28}$. Some decades later, Davutoğlu's foreign policy ${ }^{29}$ well represented the role played by religion in foreign policy as both a specific theme in international relations and a soft power tool. As Kepel highlighted ${ }^{30}$, starting from 1975 the political potential of Islam has re-emerged although modernising élites (such as the Kemalist ruling class) had concealed it during their struggle for national independence. In Turkey's case, the politicization of Islam in the 80 s occurred in spite of the Army's will to cleanse society from radical ideologies, which confirms that political use of religion was fostered by the regime with the illusion of obtaining more social control. The awakening of Islam followed two parallel processes: on the one hand, the de-privatization of religious faith; on the other hand, the policies of privatization, liberalization and globalization in the economic field, where capitals detained by religious groups shaped a new middle and business class.

Turkish Islam is also significant with regard to the relation between religion and nationalism: if the nation-State monopolized patriotic sentiments and created a sort of civilian religion - such as the Atatürkism -, in fact, it did not prevent the use of traditional religious elements by secular élites. Therefore, nationalist movements often adopt religious claims and contemporary political Islam itself ended up expressing an oppositional national identity, as in the case of Erbakan's National View ${ }^{31}$ in the 70s. Moreover, it should not be undermined that Muslim nationalism had been the driving force and unifying

26. See M. Sevinç, Anayasa yazllarl [Writings on the Constitution] (Ankara: İmaj Yayınevi, 2013), 90.

27. P. Hatzopoulos and F. Petito, Ritorno dall'esilio. La religione nelle relazioni internazionali [Return from exile. Religion in international relations] (Milano: Vita e Pensiero, 2006).

28. P. Ferrara, Religioni e relazioni internazionali. Atlante Teopolitico [Religions and international relations. Theopolitical Atlas] (Roma: Città Nuova, 2014).

29. See Y. Benhaim and K. Öktem, "The rise and fall of Turkey's soft power discourse," European Journal of Turkish Studies 21(2015).

30. G. Kepel, La rivincita di Dio [The revenge of God] (Milano: Rizzoli, 1991).

31. The National Outlook (Milli Görüss) promoted a path to development based on national, traditional and religious values. Erbakan moderated anti-imperialist and anti-Western approach in the $90 \mathrm{~s}$. 
factor of the fight for independence led by Mustafa $\mathrm{Kemal}^{32}$. Ultimately Muslim nationalism, appealing to anti-Western sentiments rooted into Turkish population, proved as much or even more successful than secularist nationalism.

Eventually, the compatibility between Turkish nationalism and Islamic faith is due to a strong sense of community, which facilitates the success of political formations reproducing a communitarian dimension ${ }^{33}$. On these grounds, we can recognise three different and perfectly compatible states of Turkish Right: conservatism, nationalism and Islamism ${ }^{34}$. Movements inspired by these ideologies eroded Marxist groups' influence and gained the spaces of youth revolts exploded at the end of the 60s in Turkey, too. Muslim pious organizations spread in the popular neighbourhoods by providing care and education services and favouring a re-Islamization from below, in opposition both to Kemalist secularization and top-down Islamization adopted in countries like Iran. Governments, in turn, supported religious groups to maintain social peace, neglecting the fact that even moderate movements express a radical criticism towards post-colonial élites' allogeneic modernization and their implicit Kemalism ${ }^{35}$.

Gülen's religious community is the most successful example of such Muslim organizations: active since the $60 \mathrm{~s}$ in the education field with the mission to educate a "Golden Generation" capable of realizing Muslim values $^{36}$, at the beginning it displayed strongly anti-communist and nationalist elements. During the crucial twenty years, the movement experienced a first wave of expansion inside the institutions and on the global stage ${ }^{37}$. With the rise of AKP to power and after the trauma of $11^{\text {th }}$ September 2001, Gülen became a natural ally for Erdoğan's project of moderate Islam as well as for the US-led "Greater Middle East" plan, aiming this time to promote a model of Muslim democracy throughout the Islamic world ${ }^{38}$. However, the changes in national and international conditions - as has been said -produced a rift between the party and the movement. Although there are currently no historical certainties about the responsibilities of the Gülenist movement in the failed coup, it is sure that it was one of the main actors in the awakening of Islam in the country, while becoming the best-known Turkish Islamic movement abroad. During AKP era, Hizmet also constituted a real political

32. E.J. Zürcher, "The vocabulary of Muslim nationalism," International Journal of the Sociology of Language no. 137(1999): 81-92.

33. Ö. Çaha, Türkiye'de seçmen davranışı ve siyasi partiler, 141-150.

34. T. Bora, Türk Sağının üç hali. Milliyetçilik, Muhafazakarlı, İslamcılık [The three states of Turkish Right. Nationalism, Conservatism, Islamism] (Istanbul: İletişim Yayınları, 2015).

35. P. Ferrara, Religioni e relazioni internazionali. Atlante Teopolitico, 107.

36. See Y. Çobanoğlu, "Altın Nesil" peşinde. Fethullah Gülen'de toplum, devlet, ahlak, otorite [On the traces of the "Golden Generation". Society, State, ethics, authority in Fethullah Gülen] (Istanbul: İletişim Yayınları, 2012).

37. For an analysis of the movement, see H. Yavuz, "The Neo-Nur Movement of Fethullah Gülen," in Islamic political identity in Turkey (New York: Oxford University Press, 2003), 179-205.

38. See the book by the ex CIA member G. Fuller, The new Turkish Republic: Turkey as a pivotal State in the Muslim world (Washington: United State Institute of Peace press, 2007). 
force penetrating the State and organizing inside civil society through associations, media, financial and educational institutions.

\section{The Failure of Kemalist Left}

From the perspective of internal political conditions, a decisive factor in the consolidation of Turkish Right and its Islamic version is the decline of Kemalist ideology embodied by the Republican People's Party (CHP). The party constantly kept the program drawn up by Atatürk in the 30s although it referred to a society quite far from the reality: in fact, in order to encourage the development of the country, Kemalists promoted a radical Westernization of values and culture, in the place of traditional symbols and religious beliefs largely shared by Turkish population. The problem of Kemalism lies precisely in managing the relationship between society and institutions that are oriented to a Jacobin and oppressive ideology. Because the legislation and political space reflect this official ideology, parties are subject to the risk of being banned if they do not conform and thus end up serving the State more than the citizens. On the other hand, the persistence of the coups dynamic is strictly connected to such a perspective of social engineering and top-down modernization.

In fact, the Kemalist national project defines modernization as Westernization to be pursued, if necessary, despite the people. Ultranationalist approach, exaggerating the anti-imperialist stand, also depicts Islam as a decisive element of national identity, so that being Turk and being Muslim - the so-called Turkish-Islamic synthesis - are two complementary features. This tendency is typical of MHP, the Nationalist Movement Party that is nowadays de facto allied with AKP in Parliament.

Even though CHP opened to a "centre-Left" version since 1965, it was not able to expand its consensus because of the continuous dilemma between the stickiness to pure Kemalism and the adoption of an authentic socialdemocratic program. Due to the persistence of chauvinist expressions, inclusion and support of minorities is impossible, as shown by the destiny of several centre-Left parties soon abandoned by the Kurdish deputies throughout the 90s. At the same time, the unsolved contradictions of Kemalist politics have determined the failure of the whole Turkish Left (both social-democratic and socialist), that historically shares the Kemalist program and approach.

Actually, we should think of Kemalism as "Kemalisms", intending an ideology that fostered at least two different political tendencies ${ }^{39}$ : while Right Kemalism refers to the most radical and ultra-nationalist interpretation of Atatürk's principles, Left Kemalism represents a unique experience in Turkish politics. Indeed, thanks to the liberal environment introduced by the 1961 Constitution, a large part of Turkish Socialist movement progressively turned to the ideas of Atatürk, who had had himself supporters coming from a Marxist

39. See T. Bora, Y. Taşkın "Sağ Kemalizm" ["Right Kemalism"], in Modern Türkiye'de siyasi düşünce. Kemalizm [The political thought in modern Turkey. Kemalism], vol. 2, (Istanbul: İletişim Yayınları, 2009), 529-545. 
background and interpreting Kemalism as a "third way" in opposition to capitalism and socialism ${ }^{40}$. In the $60 \mathrm{~s}$, similarly, intellectuals from magazines like Forum and Yön ("Direction") were convinced that it was necessary to boost national development through an enlightened élite in order to reach a better level of civilization, democracy and social justice. This could be realized not through a Marxist-Leninist revolution or a capitalistic program but establishing some sort of socialism with Turkish characteristics, namely statist, anti-imperialist, nationalist and secularist. With this in mind, Leftist Kemalists believed in the necessity of an alliance with the progressive forces in the Army ${ }^{41}$. The spread of such ideas was so wide to shape a coup attempt by a "Leftist" junta on $9^{\text {th }}$ March 1971, just few days before the military memorandum that would mark an authoritarian watershed and prepare the ground for 1980 coup.

While the so-called "national democratic revolution" slogan fuelled socialist organizations even in their radical and armed spin-offs, the CHP proved incapable of forming a stable government and realizing its Secretary Bülent Ecevit's social-democratic program. Therefore the Left, despite having become a collective political movement with an apex between 1974-1980 and then again at the beginning of the 90s, never elaborated an alternative to Kemalist tradition, marginalised from specific demands (such as those coming from the Kurds) and consumed itself in bloody infightings.

Küçükömer ${ }^{42}$ is the author of the earliest analysis of Turkish Left's ambiguity, paradoxically balanced out by the Right: in 1969 he spoke of an anomaly in Turkish politics, where the Left is actually conservative (as the Right is supposed to be) while Islamic-conservative masses supporting the Right are progressive. Such an alienation of the order depends on the fact that in Turkey the Left has always preferred to use religion as an ideological dividing line rather than "social" values asserted by the Leftists in other countries. Mostly being secularist, anti-imperialist, revolutionary or coup plotter, Turkish Left thus contributed to the despotic State and the oppression of civil society. On the contrary, Right parties opposing Kemalism have represented the real progressive forces in the national political arena: formations that would have been reactionary in other countries actually promoted the major liberalization attempts, although the economic and political liberalization has not corresponded to the establishment of a pluralist democracy.

\section{Paradigms of Modernization in Turkey's History}

According to political scientist $\mathrm{Çaha}^{43}$, the tension between Right and Left movements is ultimately due to the existence of two different

40. A. Mango, Atatürk. The biography of the founder of modern Turkey, 477-478.

41. Ö. M. Ulus, The Army and the radical Left in Turkey: military coups, socialist revolution and Kemalism (London: I.B. Tauris, 2010).

42. İ. Küçükömer, Batılaşma. Düzenin yabancllaşması [Westernization. Alienation of the regime] (Istanbul: Profil Yayıncılık, 2014).

43. Ibid., 249-250. 
modernization paradigms in Turkey's history. The synthetic-moderate paradigm was embraced around 1860 by Young Ottomans, who wanted to pursue modernization through a fusion of European political values with the local ones. The second approach was instead one of radical refusal, preferred by the Young Turks and the CUP: inspired by French Jacobinism, they aimed to a radical imposition of the European model with no care for popular traditions and beliefs.

During the single-party government ended in 1950, the CHP maintained such a forced modernization attitude, which inevitably led the party to establish an authoritarian rule, even though its original goals were democratic development and integration into contemporary civilization. The consequence was a conflict between "practical Kemalism" and "theoretical Kemalism"44, the one based on a de facto fusion between the State and the party, the latter bound to its enlightened roots and the ideals of democracy and modernity. According to some scholars ${ }^{45}$, such a contradiction is the source of conservatism in Kemalist ideology, pushed towards an authoritarian model by concrete difficulties in governing. Hence, Kemalist experience paradoxically generated Turkish conservatism and determined the authoritarian essence of any process of modernization in the country.

In fact, centre-Right conservative parties took up the Kemalist unfulfilled promise of liberal modernization in line with the Young Ottomans and fostered a synthesis between modern and national (particularly religious) values. On this basis, from the government of the Democrat Party (1950-1960) on, the centre-Right realized the most significant attempts of political and economic liberalization in the country. While doing so, it also favoured a moderate and Herodian attitude ${ }^{46}$ among most of Turkish religious groups that gradually abandoned anti-system claims thanks to their inclusion in the democratic mechanisms.

Turkish centre-Right underwent a major transformation during Özalian decade, when a neoliberal discourse substituted for the first time the Kemalist model of tutelary modernization and the idea of Turkish people's monolithic unity $^{47}$. Özal rebuilt the Right according to middle classes' expectations and global capitalistic priorities, excluding those sections of populations accused of being unable to accept the needs of the century. Therefore, Özalian age marked the definitive dismissal of Kemalist and Marxist Left's influence, as well as the real beginning of Islamic rise, since Özal himself did not hide his religious identity as a member of Nakşibendi sufi order.

AKP, presenting itself as Özal's successor, went further in the neoliberal policies and supported the consolidation of the Islamic business class as well

44. Ibid., 245-246.

45. H. U. Aktaşl1, "Muhafazakarlık ve Kemalizm: Diyalektik bir ilişki" ["Conservatism and Kemalism: a dialectic relationship"], Doğu Batı 58 no. 14 (2011): 147-161.

46. Ibid., 279; it is a definition used by Arnold Toynbee to describe the reactions of religious groups towards Westernist modernization. Herodian attitude supports integration with global neoliberal order, while the Zealot completely refuses it.

47. See the interview with Y. Taşkın, Özal ne demokrasi kahramanıydı ne de mürteci [Özal was neither a hero of democracy or a reactionary], Politikyol, accessed April 18, 2008, http://bit.ly/2yF412N. 
as a new intellectual cadre. In this way, it concluded the separation from the Virtue Party (Fazilet Partisi), yet another political formation inspired by Erbakan where the future founders of AKP distinguished themselves as promoters of renovation and liberal-conservatism. In fact, the birth of AKP in 2001 was the result of a split inside the National Outlook movement led by Erbakan since the foundation of the first Islamic party in 1970. Strongly connected to the Nakşibendi religious order and characterized by a strict internal hierarchy, the Milli Görüş expressed the growing interests of Anatolian petite bourgeoisie eager to contribute to the country's modernization. Nevertheless, the cadres of Refah (the most successful party in the movement's history) continued to be confused in the choice between democracy and sharia $^{48}$, losing the possibility of becoming the legitimate representative of Turkish centre-Right and rejecting the demands for more transparency and horizontality expressed by the liberal wing. The latter then founded the Justice and Development Party under the charismatic leadership of Recep Tayyip Erdoğan and came to government just one year after the birth of the party.

After a long militancy in the Milli Görüş and thanks to the popularity gained as a mayor of Istanbul between 1994 and 1998, at the end of the crucial twenty years Erdoğan experienced what journalist Çakır ${ }^{49}$ called a real "conversion" from his Islamist past to a new democratic-conservative image, on the model of European Christian Democrat parties ${ }^{50}$. However, contrary to the premises, recent events suggest that even AKP was not able to escape the structural authoritarianis ${ }^{51}$ of Turkish regime and probably just aimed to substitute the former Kemalist "owners" of the State rather than democratize it. The preservation of Kemalist regime's essential features is confirmed by the fact that AKP never amended the preamble and the first articles of the 1982 Constitution (the most problematic from a democratic perspective) ratifying the fundamental characteristics of the State.

Ultimately, Turkish authoritarian model is likely to be a result of several factors: on the one hand, it is surely fostered by the nature of institutions and political culture dominating in the country since the late Ottoman Empire. On the other hand, it seems to function both as an instrument of modernization and as a model of response to crises produced by international/domestic circumstances and protracted government of one single political force. As Zürcher ${ }^{52}$ highlighted, the instrumentalization of Islam too is a decisive element in Turkish authoritarianism that resorts to religion in various ways according to the crisis it has to face.

48. R. Çakır, Ne şeriat ne demokrasi. Refah Partisini anlamak [Neither sharia or democracy. Understanding the Welfare Party] (Istanbul: Metis Yayınlar1, 1994).

49. R. Çakır and F. Çalmuk, Recep Tayyip Erdoğan. Bir dönüşüm öyküsü [Recep Tayyip Erdoğan. The story of a transformation] ( Istanbul: Metis Yayınları, 2001). 2003)

50. See Y. Doğan, Muhafazakar demokrasi [Conservative democracy] (Ankara: Ak Parti,

51. See A. İnsel, "Otoritarizmin sürekliliği" ["The continuity of authoritarianism"], Birikim no. 125-126(1999): 143-166.

52. E.J. Zürcher, Islam in the service of the national and pre-national State: the instrumentalisation of religion for political goals by Turkish regimes between 1880 and 1980 . 


\section{Conclusions}

Almost fifteen years later, AKP still enjoys its electors' support: even better, it extended its consensus from the 34\% of votes gained in 2002 to the current $50 \%$ circa. However, although the party apparently managed to turn the conservative and nationalist votes to its advantage, in June 2015 election it had unexpectedly lost the majority in the Parliament. Being impossible to establish a coalition government, the country got back to the ballot box the following November, in an atmosphere of tension and terror caused by various attacks.

The party's crisis and the regime's authoritarian turn make us reconsider, on the one hand, AKP's ability to meet social pressures for an opening and diversification of the political class, as well as for a fairer distribution of economic benefits. On the other hand, the real chances of a synthesis between Turkish society's traditional values and the Western ones. Contrary to Kemalism, AKP seemed to embody successfully such a synthesis at the beginning of the millennium. However, as the years passed, Islamic centreRight too has proved incapable of realizing an enduring democracy and limited the liberalization to economy and civil society. In this sense, Erdoğan's movement was successful in mobilizing masses and integrating Islamicconservative groups into political life and global markets through a "passive revolution" ${ }^{53}$. Nevertheless, it has never renounced the Kemalist approach to State, so that some scholars comment on AKP's experience as a form of new or post-Kemalism ${ }^{54}$, also in the light of the national-Islamic discourse recently adopted $^{55}$. In conclusion, elements of continuity between Kemalism and Islamism are much more than a constant conflict or a pure cause-and-effect relationship would explain. Considering the ambiguities of Kemalist ideology and the problematic nature of Turkish secularism, it can even be argued that political Islam has taken advantage of Kemalist ideals and institutions (such as the Directorate of Religious Affairs) and simply converted them to new religious purposes.

At this moment of Turkish democratic Islam's experiment, the more general issue of the compatibility between Islam and democracy remains unsolved and maybe complicated by the fact that secularism in Turkey was absorbed by institutions thanks to Kemalist reforms but not shared as a

53. Some scholars argued that Gülen movement is an example of Islamic activism cooperating with AKP in realizing a passive revolution. See J.D. Hendrick, "Küreselleşme, İslami aktivizm, ve Türkiye'de pasif devrim: Fethullah Gülen örneği" ["Globalization, Islamic activism and passive revolution in Turkey: Fethullah Gülen's example"], in Neoliberalizm, İslamci sermayenin yükselişi ve AKP (Istanbul: Yordam Kitap, 2013), 337-382.

54. See R. Ö. Dönmez, "Adalet ve Kalkınma Partisi: İslamcılıktan post Kemalist bir anlatıya doğru" ["The Justice and Development Party: from Islamism to a post-Kemalist discourse"], Doğu Batı, 58, no. 14(2011): 37-57.

55. See F. Açıkel, "AKP İslamcılığının üç ideolojik ve üç jeopolitik dönüşümü: İslami liberalizm, pan-İslamist popülizm ve İslamc1 ulusalcılık" ["Three ideological and geopolitical changes in AKP Islamism: Islamic liberalism, Pan-islamist populism and Islamic nationalism"], Birikim no. 332 (2016): 10-40. 
collective value. The "Turkish model"56 of Islamic liberalism, enjoying its highest popularity during Arab Springs, not only proved impossible to be exported to other Muslim countries, but stopped being effective in Turkey as well. It did fail on all sides in 2013, with the explosion of Gezi Park's anticommodification protests - soon becoming an anti-authoritarian revolt - and the implosion of the alliance with Gülenists.

It is not clear yet whether Turkey will become an "Islamic Leviathan" and if the government will adopt a model of organic Islamization of the State, differently from the opportunistic Islamization of the years '80- '97 and the oppositional secularism enhanced by 1997 military intervention ${ }^{57}$. In fact, the process of Islamization currently going on in Turkey seems a useful tool to overcome AKP's political crisis and strengthen the institutions menaced by the coup attempt.

\section{Bibliography}

Açıkel F. "AKP İslamcılığının üç ideolojik ve üç jeopolitik dönüşümü: İslami liberalizm, pan-İslamist popülizm ve İslamc1 ulusalcılık" ["Three ideological and geopolitical changes in AKP Islamism: Islamic liberalism, Pan-islamist populism and Islamic nationalism"]. Birikim no. 332(2016): 10-40.

Aktaşlı H.U. "Muhafazakarlık ve Kemalizm: Diyalektik bir ilişki" ["Conservatism and Kemalism: a dialectic relationship"]. Doğu Batı 58 no. 14 (2011): 147-161.

Aydın, S. and Y. Taşkın. 1960 'tan günümüze Türkiye tarihi tarihi [Turkish history from 1960 to nowadays]. Istanbul: İletişim Yayınları, 2014.

Benhaim Y. and K. Öktem. "The rise and fall of Turkey's soft power discourse" European Journal of Turkish Studies 21(2015).

Birand M.A. 12 Eylül. Türkiye'nin miladı [12 September. The Year Zero of Turkey]. Ankara: Doğan Kitap, 2000

Bora T. Türk Sağının üç hali. Milliyetçilik, Muhafazakarlı, İslamcılık [The three states of Turkish Right. Nationalism, Conservatism, Islamism]. Istanbul: İletişim Yayınları, 2015.

Bora, T. and Y. Taşkın. "Sağ Kemalizm" ["Right Kemalism"]. In Modern Türkiye'de siyasi düşünce. Kemalizm, vol. 2. Istanbul: İletişim Yayınları, 2009, 529-545.

Cevizoğlu, H. Generalin 28 Şubat itirafi. Postmodern darbe [The admission of the General about the $28^{\text {th }}$ February. Postmodern coup]. Ankara: Ceviz Kabuğu Yayınları, 2012.

Çaha Ö. Türkiye'de seçmen davranışı ve siyasi partiler [The attitude of electorate and political parties in Turkey]. Ankara: Orion Kitabevi, 2008.

Çakır, R. Ne şeriat ne demokrasi. Refah Partisini anlamak [Neither sharia or democracy. Understanding the Welfare Party]. Istanbul: Metis Yayınları, 1994.

Çakır, R. and F. Çalmuk. Recep Tayyip Erdoğan. Bir dönüşüm öyküsü [Recep Tayyip Erdoğan. The story of a transformation]. Istanbul: Metis Yayınları, 2001.

Çobanoğlu, Y. (2012), "Altın Nesil" peşinde. Fethullah Gülen'de toplum, devlet, ahlak, otorite, Istanbul: İletişim Yayınları.

Doğan Y. Muhafazakar demokrasi [Conservative democracy]. Ankara: Ak Parti, 2003.

56 C. Tuğal, The fall of the Turkish model. How the Arab uprisings brought down Islamic liberalism (London: Verso Books, 2016).

57. For the theory of Islamic Leviathan and the models of interaction State-Islam see Ferrara, cit. 
Dönmez R.Ö. "Adalet ve Kalkınma Partisi: İslamcılıktan post Kemalist bir anlatıya doğru" ["The Justice and Development Party: from Islamism to a post-Kemalist discourse"]. Doğu Batı 58, no. 14(2011): 37-57.

Ferrara P. Religioni e relazioni internazionali. Atlante Teopolitico [Religions and international relations. Theopolitical Atlas]. Roma: Città Nuova, 2014.

Fuller, G. The new Turkish Republic: Turkey as a pivotal State in the Muslim world. Washington: United State Institute of Peace press, 2007.

Galletti, M. Storia dei curdi [History of the Kurds]. Roma: Jouvence, 2004.

Grassi, F.L. Turchia e Balcani. Materiali per lo studio degli anni recenti [Turkey and the Balcans. Materials for the study of recent years]. Romania: Napoca Star Publishing house, 2012.

"Hayri Kırbaşoğlu: Komünistler bize "Sizin kıbleniz 6. Filo" diyorlardı, haksız değillermiş!" ["Comunists used to tell us "Your qiblah is the Sixth Fleet", they were not wrong!"]. Politikyol. Accessed August 16, 2016. http://bit.ly/2xWR1s2

Hatzopoulos P. and F. Petito. Ritorno dall'esilio. La religione nelle relazioni internazionali [Return from exile. Religion in international relations]. Milano: Vita e Pensiero, 2006.

Hendrick, J.D. "Küreselleşme, İslami aktivizm, ve Türkiye'de pasif devrim: Fethullah Gülen örneğ $i$ " ["Globalization, Islamic activism and passive revolution in Turkey: Fethullah Gülen's example"]. In Neoliberalizm, İslamci sermayenin yükselişi ve AKP, Istanbul: Yordam Kitap, 2013, 337-382.

Hoşgör E. "Islamic capital/Anatolian tigers: past and present." Middle Eastern Studies 47, no. 2(2011): 343-360.

İnsel, A. Kesintisiz OHAL ya da Cumhurun Başkanlı̆̆ rejimi [The continuous state of emergency or the regime of the President of the Republic]. Accessed January 8 , 2017. http://bit.ly/2g7B74y .

İnsel, A. "Otoritarizmin sürekliliği" ["The continuity of authoritarianism"]. Birikim no. 125-126(1999): 143-166.

İnsel, A. "MGK hükümetleri ve kesintisiz darbe rejimi, Birikim" ["The MGK governments and the continuous coup regime"]. Birikim no. 96(1997): 15-18.

Kepel, G. La rivincita di Dio [The revenge of God]. Milano: Rizzoli, 1991.

Küçükömer, İ. Batılaşma. Düzenin yabancılaşması [Westernization. Alienation of the regime]. Istanbul: Profil Yayinc1lik, 2014.

Mango A. Atatürk. The biography of the founder of modern Turkey. New York: The overlook Press, 1999.

Mardin Ş. Türkiye, İslam ve sekülarizm [Turkey, Islam and secularism]. Istanbul: İletişim Yayınları, 2015.

Mardin, Ş. "Centre-periphery relations: a key to Turkish politics?" Deadalus 102, no. 1(1973): 169-190.

"Özal ne demokrasi kahramanıydı ne de mürteci" ["Özal was neither a hero of democracy or a reactionary"]. Politikyol. Accessed April 18, 2008. http://bit. $1 \mathrm{y} / 2 \mathrm{yF} 412 \mathrm{~N}$.

Özdalga E. "The hidden Arab: a critical reading of the notion of Turkish Islam." Middle Eastern Studies 42, no. 2 (2006): 551-570.

Poulton H. Top hat, Grey Wolf and Crescent. Turkish nationalism and the Turkish Republic. New York: New York University Press, 1997.

"Prof. Dr. Yüksel Taşkn: AKP-Gülenciler kavgası, sağ cenahın "liberallerini" bu iki aktör arasında bir tercihe zorladı" ["The conflict between AKP and Gülenists forced the "liberals" of the Right front to choose between these two actors]." Politikyol. Accessed August 8, 2016. http://bit.ly/2ylz3jM.

Sabuncu, Y. Anayasaya giriş [Introduction to the Constitution]. Ankara: İmaj Kitabevi, 2014. 
Sevinç M. Anayasa yazıları [Writings on the Constitution]. Ankara: İmaj Yayınevi, 2013.

Tuğal, C. The fall of the Turkish model. How the Arab uprisings brought down Islamic liberalism. London: Verso Books, 2016.

Ulus, Ö.M. The Army and the radical Left in Turkey: military coups, socialist revolution and kemalism. London: I.B. Tauris, 2010.

Yavuz H. "The Neo-Nur Movement of Fethullah Gülen". In Islamic political identity in Turkey. New York: Oxford University Press, 2003.

Zürcher, E.J. Storia della Turchia. Dalla fine dell'Impero ottomano ai nostri giorni [History of Turkey. From the end of the Ottoman Empire to the present days]. Roma: Donzelli, 2007.

Zürcher, E.J. "'Fundamentalism' as an exclusionary device in Kemalist Turkish nationalism." In Identity politics in Central Asia and the Muslim world: nationalism, ethnicity and labour in the 20th century. London: I.B. Tauris, 2001, 209-222.

Zürcher, E.J. "The vocabulary of Muslim nationalism." International Journal of the Sociology of Language no. 137(1999): 81-92.

Zürcher, E.J. Islam in the service of the national and pre-national State: the instrumentalisation of religion for political goals by Turkish regimes between 1880 and 1980. 
